medRxiv preprint doi: https://doi.org/10.1101/2020.07.31.20162875; this version posted August 4, 2020. The copyright holder for this preprint (which was not certified by peer review) is the author/funder, who has granted medRxiv a license to display the preprint in perpetuity.

It is made available under a CC-BY-NC-ND 4.0 International license .

\title{
Risk factors of severity in community-acquired staphylococcal pneumonia
}

Yves Gillet, Anne Tristan, Jean-Philippe Rasigade, Mitra Saadatian-Elahi, Coralie Bouchiat, Michele Bes, Oana Dumitrescu, Marie Leloire, Céline Dupieux, Frédéric Laurent, Gérard Lina, Jerome Etienne, Philippe Vanhems, Laurent Argaud, Francois Vandenesch, and the PVL pneumonia study group $\dagger$

$\dagger$ Members listed in the Appendix

Authors' full names and academic degrees:

Yves Gillet (M.D., Ph.D.), Anne Tristan (Pharm.D., Ph.D.), Jean-Philippe Rasigade (M.D., Ph.D.), Mitra Saadatian-Elahi (Ph.D.), Coralie Bouchiat (Pharm.D., Ph.D.), Michele Bes (Ph.D.), Oana Dumitrescu (M.D., Ph.D.), Marie Leloire (M.D.), Céline Dupieux (Pharm.D., Ph.D.), Frédéric Laurent (Pharm.D., Ph.D.), Gérard Lina (M.D., Ph.D.), Jerome Etienne (M.D., Ph.D.), Philippe Vanhems (M.D., Ph.D.), Laurent Argaud (M.D., Ph.D.), Francois Vandenesch (M.D., Ph.D.).

Authors affiliations:

Pediatric Emergency \& Intensive Care Unit, Hospices Civils de Lyon, Lyon, France (Y.G.), French Reference Center for Staphylococci, Hospices Civils de Lyon, Lyon, France (Y.G., A.T., J.-P.R., C.B., M.B., O.D., C.D., F.L., G.L., J.E., F.V.)

Infection Control and Epidemiology Department, Hospices Civils de Lyon, Lyon, France (M.S.-E., Ph.V.)

Medical Intensive Care Unit, Hospices Civils de Lyon, Lyon, France (L.A.)

Corresponding author. Francois Vandenesch, email: francois.vandenesch@univ-lyon1.fr, tel: +33472003703

Alternate corresponding author: Yves Gillet, email: yves.gillet@ chu-lyon.fr, tel: +33 42785 5642 
medRxiv preprint doi: https://doi.org/10.1101/2020.07.31.20162875; this version posted August 4, 2020. The copyright holder for this preprint (which was not certified by peer review) is the author/funder, who has granted medRxiv a license to display the preprint in perpetuity.

It is made available under a CC-BY-NC-ND 4.0 International license .

\section{Background}

Staphylococcus aureus causes severe forms of community-acquired pneumonia (CAP), namely staphylococcal pleuropneumonia in young children and staphylococcal necrotizing pneumonia in older patients. Methicillin resistance and the Panton-Valentine leukocidin (PVL) toxin have both been associated with poor outcome in severe CAP, but their respective roles are unclear.

Methods

Prospective multicenter cohort study of severe staphylococcal CAP conducted in 77 pediatric and adult intensive care units in France between January 2011 and December 2016. Clinical features and outcomes were compared between toddlers ( $<3$ years of age) and older patients with PVL-positive CAP; and between older patients with PVL-negative or PVL-positive CAP. Risk factors for mortality were identified using multivariate Cox regression.

Results

Of 163 included patients, aged one month to 87 years, 85 (52.1\%) had PVL-positive CAP; there were $20(12.3 \%)$ toddlers, among whom 19 (95\%) had PVL-positive CAP. The features of PVL-positive CAP in toddlers matched with the historical description of staphylococcal pleuropneumonia, with a lower mortality $(n=3 / 19,15 \%)$ compared to PVL-positive CAP in older patients $(n=31 / 66,47 \%)$. Mortality in older patients was independently predicted by PVL-positivity (hazard ratio $1.81,95 \% \mathrm{CI}, 1.03$ to 3.17$)$ and methicillin resistance $(2.37,95 \%$ CI 1.29 to 4.34). As genetic diversity was comparably high in PVL-positive and PVLnegative isolates, confounding by microbial population structure was unlikely.

\section{Conclusion}

PVL was associated with staphylococcal pleuropneumonia in toddlers and was a risk factor for mortality in older patients with severe CAP, independently of methicillin resistance. Funded by the French ministry of Health (PHRC 2010-A01132-37). 


\section{Word count 2580.}

60

\section{Introduction}

62 Staphylococcal necrotizing pneumonia was first described in 1919 in adults during the

63 influenza pandemic. ${ }^{1}$ It is associated with airway hemorrhage, epithelial necrosis, and a high

64 fatality rate in otherwise healthy patients. ${ }^{2}$ It was seldom reported during the $\mathrm{XX}^{\text {th }}$ century ${ }^{3,4}$ 65 until the epidemiological and pathophysiological links with Panton-Valentine Leucocidin 66 (PVL) were made at the turn of the century. ${ }^{2,5}$ Subsequent reports confirmed the high fatality 67 rates $(40-50 \%)$ of PVL-associated pneumonia in adults. ${ }^{6-9}$

68 Independently of staphylococcal necrotizing pneumonia, staphylococcal pleuropneumonia

69 (SPP) in young children was described during the late 1950s and 1960s as a specific clinical 70 entity characterized by round-shaped lung infiltration evolving towards bullous lesions, 71 purulent pleural effusion, and lack of airway hemorrhage or epithelial necrosis. ${ }^{10,11}$ Recent 72 case series of SPP involving PVL-positive community-acquired S. aureus ${ }^{12,13}$ pointed to a 73 possible relationship between SPP and PVL. In these series, the fatality rate was below 5\%.

74 These strikingly different diseases, both associated with PVL, may have contributed to 75 controversies regarding the impact of PVL on the severity of staphylococcal pneumonia. ${ }^{14-16}$ 76 In this context, whether age affects both the clinical picture and the outcome of community77 acquired PVL-positive staphylococcal pneumonia, and whether PVL is an independent factor of severity are questions that remain to be answered and which are addressed herein. 


\section{Patients and methods}

80 Ethics.

81 The regional ethics committee approved the study (number: A11-39). Written informed 82 consent was obtained from all patients or their parents.

84 Study design and participants.

85 Patients with $S$. aureus community-acquired pneumonia (CAP; criteria in Appendix) and 86 admitted to a participating intensive care unit (ICU) were included between January 2011 and

87 December 2016. Exclusion criteria were HIV-positive status, hospital-acquired pneumonia, or admission to hospital in the past 3 months. Clinical, laboratory, and therapeutic data were

89 prospectively collected, and patients were assessed at admission to ICU, on day 1, 3, and 7.

90 Severity was evaluated using age-adapted severity scores (Appendix).

91

92 Microbiology.

93 The causative staphylococcal strains were transmitted to the French National Reference

94 Centre for Staphylococci for full characterization and microarray genotyping (Appendix). ${ }^{17}$

96 Statistical analysis.

97 We determined whether the previous descriptions of different PVL-associated diseases, 98 namely SPP in children and staphylococcal necrotizing pneumonia in adults, correlated with 99 identifiable age groups in patients with severe CAP. To this aim, patterns in patient age 100 distribution were detected using a clustering procedure (Appendix, Fig. A1). Following this, 101 disease presentation and outcome in toddlers ( $<3$ years of age, as determined by the age 102 clustering procedure) were compared to that found in older patients; and in older patients 103 PVL-positive cases were compared to PVL-negative cases. The comparison of PVL-positive 
medRxiv preprint doi: https://doi.org/10.1101/2020.07.31.20162875; this version posted August 4, 2020. The copyright holder for this preprint (which was not certified by peer review) is the author/funder, who has granted medRxiv a license to display the preprint in perpetuity.

It is made available under a CC-BY-NC-ND 4.0 International license .

104 and PVL-negative cases was restricted to older patients ( $\geq 3$ years of age) because 95\% of

105 toddlers had PVL-positive CAP. Between-group comparisons used Fisher's exact test or

106 Student's t-test, as appropriate. Possibly non-linear changes of mortality rates in function of

107 patient age were visualized using kernel density estimation with bootstrap confidence

108 intervals (Appendix). Potential predictors of mortality were investigated using univariate and

109 multivariate Cox proportional hazards models. To avoid bias due to row-wise deletion of

110 cases containing missing data in multivariate models, ${ }^{18}$ all missing data were imputed prior to

111 analysis using a non-linear, random forest-based multiple imputation technique. Imputation

112 uncertainty was accounted for by replacing binary factors (such as, for example, leukopenia)

113 by a probability estimate between 0 (absence) and 1 (presence). Analyses were conducted

114 using R software v3.6.0 (R Core Team [2019]. R: A language and environment for statistical

115 computing. R Foundation for Statistical Computing, Vienna, Austria. URL https://www.R-

116 project.org/). Anonymized data and software code required to reproduce the results are

117 available at github.com/rasigadelab/severecap.

118 
medRxiv preprint doi: https://doi.org/10.1101/2020.07.31.20162875; this version posted August 4, 2020. The copyright holder for this preprint (which was not certified by peer review) is the author/funder, who has granted medRxiv a license to display the preprint in perpetuity.

It is made available under a CC-BY-NC-ND 4.0 International license .

\section{Results}

120 Clustering analysis of patient age identifies specific patterns in PVL-positive and PVL-

121 negative $S$. aureus pneumonia. A total of 245 patients were identified, and after removal of

122 those who did not comply with the inclusion criteria, without consent, and those with missing

123 CRF, 163 patients were included (Appendix, Fig. A1). These were hospitalized in 77 ICUs,

124 and aged from one month to 87 years. Overall, 85 patients $(52.1 \%)$ were infected by a PVL-

125 positive S. aureus. Clustering of patients with PVL-positive CAP identified two non-

126 overlapping clusters below and above $\sim$ three years of age, while the analysis of PVL-negative

127 S. aureus patients identified two overlapping clusters centered at 28 and 60 years of age

128 (Appendix, Fig. A2). Thus, almost all cases in patients aged of $<3$ years (hereinafter

129 “toddlers") were PVL-positive while, in older patients, PVL positivity was evenly distributed

130 according to age. In contrast, PVL-negative CAP was exceptional in younger children (only

131 one case under 15 years of age) and its prevalence increased with patient age, peaking at 60

132 years. The microbiological and clinical features of CAP differed markedly between toddlers

$133(\mathrm{n}=20)$ and older patients $(\mathrm{n}=143)$. PVL positivity was more frequent in toddlers $(\mathrm{n}=19 / 20$

134 vs. $77 / 143$; odds ratio $21.9,95 \%$ CI 3.3 to 928.6 ), more strongly so than methicillin resistance

135 ( $\mathrm{n}=7 / 20$ vs. $23 / 143$, odds ratio $2.8,95 \%$ CI 0.85 to 8.6 ). Additional results concerning the

136 specificities observed in toddlers are developed in the Appendix.

137

138 Genetic diversity of causative isolates.

139 Strain genetic background were extremely diverse; there were 13 different clonal complexes

140 (CC) in PVL-positive and $17 \mathrm{CC}$ in PVL-negative isolates, 7 of those CCs being shared by

141 the two groups (further details in Appendix).

142 
medRxiv preprint doi: https://doi.org/10.1101/2020.07.31.20162875; this version posted August 4, 2020. The copyright holder for this preprint (which was not certified by peer review) is the author/funder, who has granted medRxiv a license to display the preprint in perpetuity.

It is made available under a CC-BY-NC-ND 4.0 International license .

143 Mortality according to age. Mortality peaked at $\sim 30$ years and above 60 years (Fig. 1a-b).

144 The mortality peak at $\sim 30$ years was more pronounced in PVL-positive cases (Fig. 1c-d)

145 while the mortality peak above 60 years was stronger in PVL-negative cases (Fig. 1e-f).

146 Mortality was lower in toddlers than older patients $(n=3 / 20$ vs. $52 / 143$, odds ratio $0.31,95 \%$

147 CI 0.06 to 1.15). In toddlers with PVL-positive CAP (Fig. 1 g-h), most cases occurred before

14812 months of age and were non-lethal, while mortality increased after one year of age.

149 Since only 1 toddler had PVL-negative CAP, we could not compare the outcomes of PVL-

150 positive to PVL-negative CAP in this group. Further analysis aiming to compare PVL-

151 positive to PVL-negative cases was restricted to patients $\geq 3$ years to avoid the interpretation

152 bias that would have resulted from the pooling of markedly different patients (namely,

153 toddlers and older patients) in a single analysis.

155 PVL is a severity factor in patients $\geq \mathbf{3}$ years.

156 Among the 143 patients $\geq 3$ years, 66 (46.2\%) had PVL-positive CAP. Compared to PVL157 negative CAP, patients with PVL-positive CAP were younger and less likely to have an 158 underlying condition (Table 1). At admission, they had more frequently airway hemorrhage 159 and cutaneous eruption or rash evoking immune system reaction. PVL-positive CAP patients 160 were also more likely to present with septic shock, leukopenia, elevated blood lactate and

161 SOFA severity score, and to require extra corporeal membrane oxygenation (ECMO).

162 Appropriate initial antibiotic treatment, defined as at least one drug active against the 163 corresponding strain, was equally likely in PVL-positive and PVL-negative CAP. However,

164 treatment was less frequently appropriate in MRSA cases (odds ratio 0.027, 95\% CI 0.006 to

165 0.097). See Appendix for additional information on antibiotic treatment.

166 Most of the differences observed between patients with PVL-positive and PVL-negative CAP

167 at admission persisted during the first week in ICU (Table 2). The higher SOFA score at 
medRxiv preprint doi: https://doi.org/10.1101/2020.07.31.20162875; this version posted August 4, 2020. The copyright holder for this preprint (which was not certified by peer review) is the author/funder, who has granted medRxiv a license to display the preprint in perpetuity.

It is made available under a CC-BY-NC-ND 4.0 International license .

168 admission persisted at day 1 , as did the higher median blood lactate. Temperature $>39^{\circ} \mathrm{C}$,

169 airway hemorrhage, and rash remained significantly more common in PVL-positive cases,

170 who received more frequently inhaled nitric oxide and required ECMO support.

171

\section{Survival.}

173 We used survival analysis to examine the influence of microbiological and clinical factors on

174 lethal outcome in the 143 patients $\geq 3$ years of age. Kaplan-Meier survival curves suggested

175 that PVL-positivity and methicillin resistance contributed additively to mortality (Fig. 2);

176 median survival time was 1 day (interquartile range, IQR 0 to 7 days) for PVL-positive cases

177 and 7 days (IQR 3 to 14 days; $\mathrm{P}=0.02$, Mann-Whitney $U$-test) for PVL-negative cases.

178 Among the 91 survivors, length of ICU stay was longer in those with PVL-positive CAP

179 (median time until discharge, 39 days, IQR 26 to 68 days) than in those with PVL-negative

180 CAP (29 days, IQR 20 to 42 days; $\mathrm{P}=0.01$, Mann-Whitney $U$-test). A multivariate Cox

181 regression model also supported an independent association of PVL-positivity (adjusted

182 hazard ratio, aHR $1.8,95 \%$ CI 1.04 to 3.2) and methicillin-resistance (aHR 2.4, 95\% CI 1.3 to

183 4.4) with mortality. We used bivariate and multivariate Cox proportional hazards models to

184 identify potential independent risk factors for mortality (Table 3). Predictors were included in

185 the models based on their expected relevance to disease outcome. These included baseline

186 patient characteristics, namely, sex and the Charlson comorbidity score; microbiological

187 factors, namely, PVL and methicillin resistance; patient characteristics reflecting: (1) severity

188 upon admission, namely, the SOFA score, hemoptysis, leukopenia and blood lactates, (2)

189 inflammatory reaction, namely rash and blood procalcitonin, (3) a risk factor for

190 staphylococcal superinfection of the lung, namely, a flu-like illness; and the appropriateness

191 and expected toxin-suppressing activity of the antibiotics received (see Appendix for details).

192 In the best-fitting multivariate model, the independent predictors of death were methicillin 
medRxiv preprint doi: https://doi.org/10.1101/2020.07.31.20162875; this version posted August 4, 2020. The copyright holder for this preprint (which was not certified by peer review) is the author/funder, who has granted medRxiv a license to display the preprint in perpetuity. It is made available under a CC-BY-NC-ND 4.0 International license.

193 resistance, hemoptysis, rash, leukopenia, elevated blood lactates, and the absence of a flu-like

194 illness. Interestingly, the best-fitting model did not include PVL-positivity but included 195 previously recognized severity factors in PVL-positive lung infection, ${ }^{19}$ namely, hemoptysis 196 and leukopenia. The exclusion of PVL, but not its clinical consequences, from the final model

197 is suggestive of a chain of consequence between PVL, severity factors and death, where the

198 severity factors mediate the effect of PVL on death. ${ }^{20}$ See Appendix for additional data on 199 severity-associated features and on interactions between predictors of mortality. 
medRxiv preprint doi: https://doi.org/10.1101/2020.07.31.20162875; this version posted August 4, 2020. The copyright holder for this preprint (which was not certified by peer review) is the author/funder, who has granted medRxiv a license to display the preprint in perpetuity.

It is made available under a CC-BY-NC-ND 4.0 International license .

200

201

202

203

204

205

206

207

208

209

210

211

212

214

215

216

217

218

220

221

222

223

224

\section{Discussion}

As the present study is one of the largest prospective series of PVL-positive S. aureus pneumonia and is the first to compare PVL-positive and -negative cases since the description of staphylococcal necrotizing pneumonia in $2002,{ }^{2}$ we are able to better understand the role of PVL in different clinical presentation and in severity of staphylococcal pneumonia.

PVL-positive CAP and its severity was not evenly distributed according to age. PVL-negative CAP was virtually absent in toddlers and mortality was low. Many infectious processes vary in terms of presentation between young and older subjects, but the differences we observed exceed the expected variations due to age alone. For instance, radiological findings in pneumonia are usually similar at all ages, ${ }^{21}$ however, we observed substantial radiological differences, notably regarding pleural effusion, pneumothorax and unilateral involvement that were more frequent in toddlers. It was also unexpected to observe a lower mortality in very young children compared to young adults without underlying conditions. Thus, despite similarities in terms of site of infection and bacteriology, staphylococcal CAP of the young children (i.e. SPP) and staphylococcal necrotizing pneumonia of the adults should be considered as two distinct entities.

As we uncovered major differences according to age in PVL-positive staphylococcal pneumonia, the lack of consideration of age-specificity of the disease severity may at least partially explain some conflicting results reported in the literature. ${ }^{14,22}$ Considering that PVLnegative staphylococcal pneumonia are almost absent in the youngest patients, toddlers should be excluded from analysis to assess the role of PVL in severity.

We observed that PVL was associated with specific symptoms in staphylococcal pneumonia of adolescents and adults. Previously described features strongly associated with $\mathrm{PVL}^{2,7}$ were observed herein among patients aged $\geq 3$ years: PVL-positive $S$. aureus pneumonia occurred mainly in younger people without underlying condition and was associated with cutaneous 
medRxiv preprint doi: https://doi.org/10.1101/2020.07.31.20162875; this version posted August 4, 2020. The copyright holder for this preprint (which was not certified by peer review) is the author/funder, who has granted medRxiv a license to display the preprint in perpetuity.

It is made available under a CC-BY-NC-ND 4.0 International license .

225 rash, airway hemorrhage, and leukopenia. Strikingly, PVL was associated with rash

226 independently of major superantigens. Because PVL itself has no known superantigenic

227 properties, it is unclear whether this association reflects a direct effect of PVL or a less-

228 specific consequence of severe inflammation.

229 Airway hemorrhage is a consequence of respiratory epithelial necrosis, as described in lung

230 autopsies, ${ }^{1,2}$ and is an indirect effect of PVL since the presence of polymorphonuclear (PMN)

231 cells in the lung is required for PVL-induced necrotic lesions of the epithelium. ${ }^{23}$ PMN cell

232 influx to the lung may be generated by two non-exclusive mechanisms: a preceding viral

233 infection producing chemoattractant for neutrophils by epithelial cells, ${ }^{23}$ and a consequence of

234 PVL-mediated inflammasome activation, leading to PMN cell recruitment and activation. ${ }^{24}$

235 One objective of the present study was to assess the link between PVL and severity,

236 considering that such an association has been controversial since the first description of PVL-

237 associated pneumonia in 2002. ${ }^{2}$ The frequency of PVL in severe CAP in adults herein

238 contrasts with the low frequency of PVL $(<5 \%)$ in the staphylococcal carriage population in

239 France $^{17}$ and this striking difference constitutes the initial evidence for an association of PVL

240 with severity. We observed that PVL, especially but not exclusively when associated with

241 methicillin resistance, was an independent factor of mortality in staphylococcal CAP,

242 outweighing protective factors such as young age and absence of underlying conditions. The

243 present study indicates that PVL is associated with non-specific severity markers of infection

244 such as elevated lactate or presence of septic shock at admission and absence of reduction in

245 lactate between admission and day 1 . All these factors are associated with a higher mortality

246 in sepsis, irrespective of the bacteria involved, ${ }^{25,26}$ and their higher frequency in the PVL-

247 positive cases confirms greater severity in such patients. Surrogate markers of respiratory

248 failure, such as the need for nitric oxide and for ECMO, were more frequent in PVL-positive

249 cases, which also indicates greater severity in accordance with recent studies. ${ }^{27-28}$ The 
medRxiv preprint doi: https://doi.org/10.1101/2020.07.31.20162875; this version posted August 4, 2020. The copyright holder for this preprint (which was not certified by peer review) is the author/funder, who has granted medRxiv a license to display the preprint in perpetuity.

It is made available under a CC-BY-NC-ND 4.0 International license .

250 symptoms associated with PVL (i.e. rash, airway hemorrhage, and leukopenia) were

251 associated with mortality in the multivariate prediction model, strongly suggesting that these

252 clinical factors mediate the link between PVL and death.

253 Since its first description, ${ }^{2}$ PVL-positive S. aureus pneumonia has been reported

254 worldwide. ${ }^{28-31}$ A particular situation is observed in the USA where the description of

255 necrotizing pneumonia coincided with the emergence of the PVL-positive CA-MRSA

256 USA300 lineage. ${ }^{4,32}$ PVL has been also associated with the CA-MRSA ST-80 lineage in

257 Europe. ${ }^{33}$ However, only 11 and five strains of the present study belong to these clones,

258 respectively, and PVL was distributed within a large diversity of genetic background (i.e. 13

259 CCs) with a majority of MSSA, ruling out a possible clonal bias associated with PVL-positive

260 cases. The particular lineage restriction observed in the US may have led to confusion in the

261 understanding of the determinant of severity associated with staphylococcal CAP. Thus,

262 methicillin resistance was thought to be the prominent determinant for severity, presumably

263 by inducing a delay in initiation of appropriate antibiotics. The present study found that

264 patients infected with MRSA were less likely to have received appropriate antibiotics at

265 admission and had a worse prognosis. However, this higher mortality in MRSA was present

266 both in PVL-positive and PVL-negative-pneumonia patients.

267 The present study does, however, have certain limitations, most notably the observational

268 design whereby all participating centers were encouraged to enroll patients fulfilling the

269 inclusion criteria. We cannot exclude under-reporting, and a higher reporting of the most

270 severe cases may have occurred, but this is unlikely to have affected directly the comparison

271 between PVL-positive and PVL-negative cases. The number of missing data were limited and

272 exhaustivity was reached for all major parameters. Furthermore, the study was restricted to

273 France but covers almost entirely the French territory with 77 participating centers thus

274 limiting possible local epidemiological bias. 
medRxiv preprint doi: https://doi.org/10.1101/2020.07.31.20162875; this version posted August 4, 2020. The copyright holder for this preprint (which was not certified by peer review) is the author/funder, who has granted medRxiv a license to display the preprint in perpetuity.

It is made available under a CC-BY-NC-ND 4.0 International license .

276 In conclusion, the present study demonstrates the association of PVL with two distinct facets

277 of staphylococcal CAP with marked differences between toddlers and adolescents/adults

278 regarding clinical presentation and outcome. In toddlers, PVL appears to be prominent in

279 staphylococcal pneumonia, presentation matches with SPP, and standard of care in modern

280 ICU appears to be sufficient for favorable outcome. In contrast, PVL-positive CAP in

281 adolescents and adults remains extremely severe despite aggressive management; it deserves

282 further research to develop a novel therapeutic approach.

283

284

285

286 Contributors

287 YG designed the study, analyzed and interpreted data, and wrote the report

288 AT collected and analyzed data, and revised the report.

289 JPR performed statistical analysis, interpreted data and wrote the report.

290 MSE contributed to design the study, collected data, and revised the report.

291 CB collected and analyzed data, and revised the report.

292 MB analyzed the microbiological data, and revised the report.

293 OD collected and analyzed data, and revised the report.

294 ML collected and analyzed data, and revised the report.

295 CD collected and analyzed data, and revised the report.

296 FL analyzed the microbiological data, and revised the report.

297 GL contributed to design the study and revised the report.

298 JE contributed to design the study and wrote the report. 
medRxiv preprint doi: https://doi.org/10.1101/2020.07.31.20162875; this version posted August 4, 2020. The copyright holder for this preprint (which was not certified by peer review) is the author/funder, who has granted medRxiv a license to display the preprint in perpetuity.

It is made available under a CC-BY-NC-ND 4.0 International license .

299 PV contributed to design the study, contributed to statistical analysis, interpreted data and

300 revised the report.

301 LA designed the study, interpreted data, and revised the report.

302 FV designed the study, acquired funding and ethics approval, is the chief

303 investigator of the study, and wrote the report.

304 All authors read and approved the final report.

305

306 Declaration of interests

307 FV have received a grant from the French Ministry of Research for the submitted work, has

308 received grants from bioMérieux, and has been a consultant for Pfizer and Acccelerate

309 Diagnosis.

310 YG has been a consultant for Pfizer vaccine, GSK Vaccines and Sanofi-Pasteur MSD

311 vaccines.

312 AT has received a grant from bioMérieux and R-biopharm.

313 JPR has received grants from bioMérieux; and honoraria for lecturing from Pfizer, MSD and

314 Procter\&Gamble.

315 CB has received a grant from bioMérieux and Pathoquest.

316 GL has received a grant from Pfizer, Novartis, Basilea, Diadenode and Pierre Fabre, and has

317 been consultant for Eumedica, GenMark and Beckton Dickinson.

318 OD has received a grant from the French Ministry of Research and from Pfizer.

319 CD has received honoraria for lecturing from Correvi.

320 PV has received personnal fees for expertise and consulting from GSK, Astellas, Pfizer and

321 bioMerieux, and received research grant from Sanofi, MSD and ANIOS.

322 The other authors declare no competing interests.

323 
medRxiv preprint doi: https://doi.org/10.1101/2020.07.31.20162875; this version posted August 4, 2020. The copyright holder for this preprint (which was not certified by peer review) is the author/funder, who has granted medRxiv a license to display the preprint in perpetuity. It is made available under a CC-BY-NC-ND 4.0 International license.

\section{Acknowledgments}

325 The study was funded by French Ministry of Health under the Programme Hospitalier de 326 Recherche Clinique 2011. This report presents independent research commissioned by the 327 Ministry of Health; the views and opinions expressed in this publication are those of the 328 authors and do not necessarily reflect those of the Ministry of Health. We thank the 329 technicians of the French Reference Centre for Staphylococci for their contribution in 330 characterizing S. aureus isolates. Finally, we thank Philip Robinson (DRCI, Hospices Civils 331 de Lyon) for copy-editing the manuscript.

332

333

334 
medRxiv preprint doi: https://doi.org/10.1101/2020.07.31.20162875; this version posted August 4, 2020. The copyright holder for this preprint (which was not certified by peer review) is the author/funder, who has granted medRxiv a license to display the preprint in perpetuity.

It is made available under a CC-BY-NC-ND 4.0 International license .

335

336 Tables

337 Table 1: Clinical and laboratory characteristics at admission and during stay according to PVL status in 338 patients $\geq \mathbf{3}$ years of age. $*$

\begin{tabular}{|c|c|c|c|c|c|}
\hline & \multicolumn{2}{|c|}{ PVL-positive S.aureus } & \multicolumn{2}{|c|}{ PVL-negative S.aureus } & \multirow[b]{2}{*}{$\mathbf{p}$} \\
\hline & $(n=66)$ & missing & $(n=77)$ & missing & \\
\hline $\begin{array}{l}\text { Mean delay between onset and ICU } \\
\text { admission,(SD) }\end{array}$ & $3.39(3.74)$ & $\mathbf{0}$ & $4.64(4.80)$ & 4 & 0.092 \\
\hline \multicolumn{6}{|l|}{ Initial condition } \\
\hline $\operatorname{Sex}(F / M)$ & $31 / 35$ & 0 & $27 / 50$ & 0 & 0.173 \\
\hline Median age, years [IQR] & $47[28.7-60.2])$ & 0 & $58[48.0-67.0]$ & 0 & $<0.001$ \\
\hline Children < 18 years $(\%)$ & $6(9.1)$ & 0 & $1(1)$ & 0 & 0.049 \\
\hline MRSA (\%) & $14(21.2)$ & 0 & $9(11.7)$ & 0 & 0.170 \\
\hline Tobacco smoking (\%) & $11(20.0)$ & 4 & $31(42.5)$ & 11 & 0.008 \\
\hline Alcohol abuse (\%) & $4(6.9)$ & 2 & $20(26.7)$ & 8 & 0.003 \\
\hline Diabetes (\%) & $8(12.3)$ & 1 & $21(27.3)$ & 0 & 0.036 \\
\hline $\mathbf{B M I}>\mathbf{3 0} \dagger(\%)$ & $3(6.5)$ & 20 & $11(16.4)$ & 10 & 0.151 \\
\hline Absence of underlying cond. (\%) & $39(59.1)$ & 0 & $22(28.6)$ & 0 & $<0.001$ \\
\hline Mean Charlson's score (SD) & $1.18(0.18)$ & 0 & $2.14(0.22)$ & 0 & 0.001 \\
\hline \multicolumn{6}{|l|}{ At admission } \\
\hline Temperature $>39^{\circ} \mathrm{C}(\%)$ & $35(53)$ & 0 & $29(38.2)$ & 1 & 0.092 \\
\hline Airway hemorrhage (\%) & $29(43.9)$ & 0 & $18(23.4)$ & 0 & 0.012 \\
\hline Toxin-mediated rash $(\%)$ & $14(21.2)$ & 0 & $5(6.6)$ & 1 & 0.013 \\
\hline Bilateral pneumonia (\%) & $46(70.8)$ & 1 & $52(68.4)$ & 1 & 0.855 \\
\hline Significant pleural effusion $\doteqdot(\%)$ & $3(4.5)$ & 0 & $1(1.4)$ & 3 & 0.343 \\
\hline
\end{tabular}


medRxiv preprint doi: https://doi.org/10.1101/2020.07.31.20162875; this version posted August 4, 2020. The copyright holder for this preprint (which was not certified by peer review) is the author/funder, who has granted medRxiv a license to display the preprint in perpetuity.

\section{It is made available under a CC-BY-NC-ND 4.0 International license .}

\begin{tabular}{|c|c|c|c|c|c|}
\hline Median leucocyte count, G/l [IQR] & $4.60[1.4-15.0]$ & 1 & $9.34[5.0-15.8]$ & 3 & 0.011 \\
\hline Leukopenia $<3 \mathrm{G} / \mathrm{L}(\%)$ & $28(43.1)$ & 1 & $14(18.9)$ & 3 & 0.003 \\
\hline Median blood lactate, mg/l [IQR] & $3.95[2.3-5.5]$ & 8 & $2.4[1.7-4.6]$ & 9 & 0.015 \\
\hline Median CRP, mg/l [IQR] & $327.5[191.2-396.7]$ & $26 \S$ & $251.6[127.0-351.0]$ & $18 \S$ & 0.041 \\
\hline Median PCT, $\mu \mathrm{g} / 1[\mathrm{IQR}]$ & $137.5[51.7-488.5]$ & $40 \S$ & $57.0[8.0-200.0]$ & $58 \S$ & 0.032 \\
\hline Appropriate antibiotics (\%) & 75.8 & 4 & 80.5 & 0 & 0.539 \\
\hline \multicolumn{6}{|l|}{$\underline{\text { During ICU stay }}$} \\
\hline Documented Influenza infection (\%) & $26(39.4)$ & 0 & $21(27.6)$ & 1 & 0.155 \\
\hline Temperature $>39^{\circ} \mathrm{C}(\%)$ & $44(75.9)$ & 8 & $44(58.7)$ & 2 & 0.043 \\
\hline Airway hemorrhage (\%) & $35(59.3)$ & 7 & $28(37.3)$ & 2 & 0.015 \\
\hline Toxin-mediated rash $(\%)$ & $15(25.4)$ & 7 & $8(10.7)$ & 2 & 0.037 \\
\hline Bilateral pneumonia (\%) & $45(78.9)$ & 9 & $61(83.6)$ & 4 & 0.505 \\
\hline Significant pleural effusion (\%) & $10(16.4)$ & 5 & $10(13.7)$ & 4 & 0.808 \\
\hline Median highest CRP, mg/L [IQR] & $352[230.0-447.0]$ & $38 \S$ & $228[106.0-347.0]$ & $38 \S$ & 0.017 \\
\hline Median highest PCT, $\mu \mathrm{g} / \mathrm{L}[\mathrm{IQR}]$ & $91[28.5-375.0]$ & $37 \S$ & $35.4[3.3-98.6]$ & $47 \S$ & 0.032 \\
\hline \multicolumn{6}{|c|}{$\begin{array}{l}* \text { Data are n (\%), median [Interquartile range] or mean (standard deviation), percentage are calculated among } \\
\text { those with data. MRSA: Methicillin resistant Staphylococcus aureus; BMI: Body Mass Index; CRP: C-Reactive } \\
\text { Protein; PCT: Procalcitonin; ICU: Intensive Care Unit } \\
\dagger \text { for adult >18years only } \\
\$ \text { needing drainage } \\
\S \text { Inflammatory markers (CRP or PCT) are missing for } 14 \text { patients ( } 7 \text { in each group) }\end{array}$} \\
\hline
\end{tabular}


medRxiv preprint doi: https://doi.org/10.1101/2020.07.31.20162875; this version posted August 4, 2020. The copyright holder for this preprint (which was not certified by peer review) is the author/funder, who has granted medRxiv a license to display the preprint in perpetuity.

It is made available under a CC-BY-NC-ND 4.0 International license .

346 Table 2: Severity scores and markers at admission and during evolution according to PVL status in

347 patients $\geq \mathbf{3}$ years of age.

348

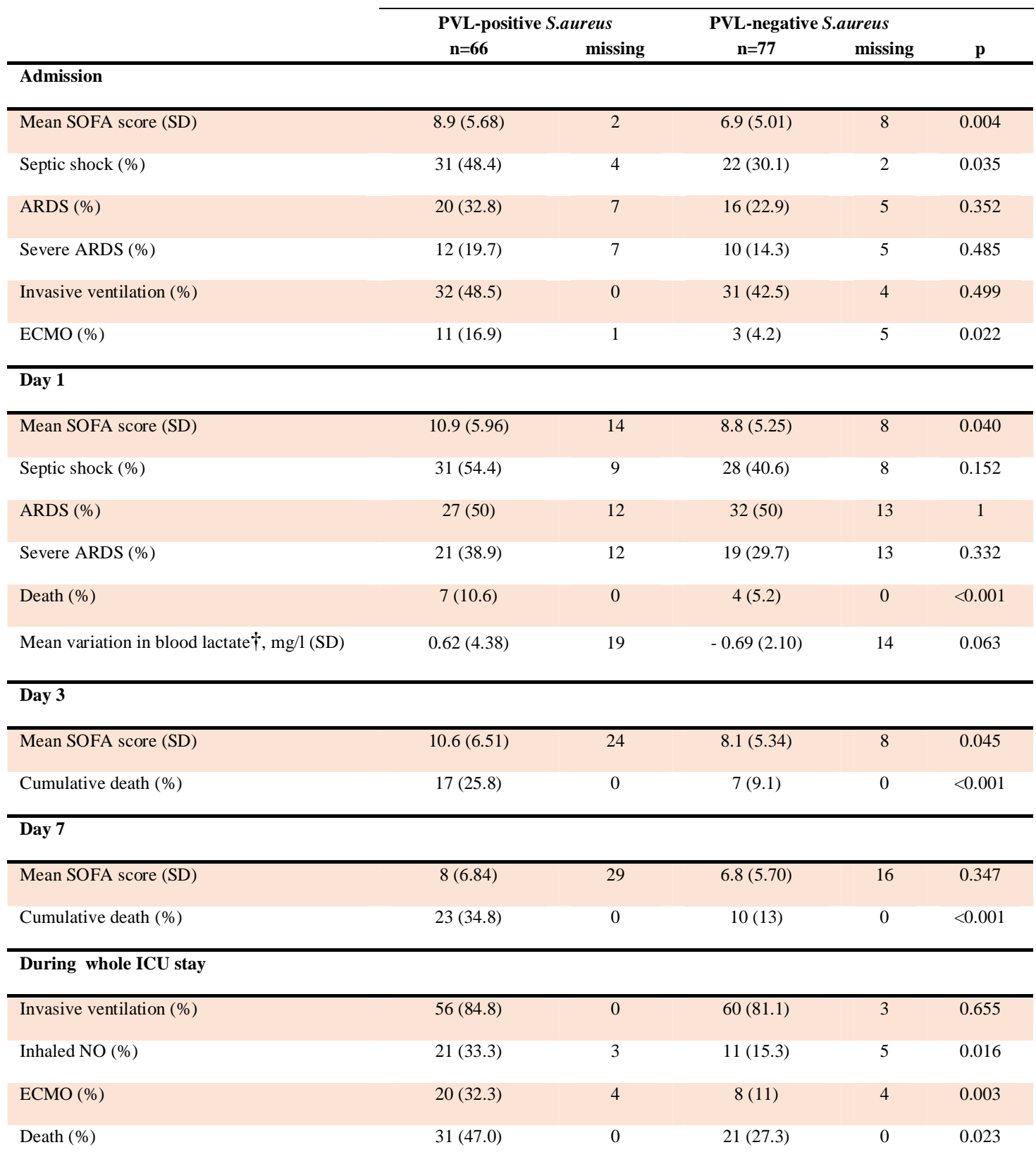

349 * Data are n (\%), mean (standard deviation), percentage are calculated among those with data. SOFA: Sequential

350 Organ Failure Assessment; ARDS: Acute Respiratory Distress Syndrome; NO: Nitrogen Monoxyde; ECMO:

351 Extra Corporeal Membrane Oxygenation

352 †between Day 0 and Day one

353 
medRxiv preprint doi: https://doi.org/10.1101/2020.07.31.20162875; this version posted August 4, 2020. The copyright holder for this preprint (which was not certified by peer review) is the author/funder, who has granted medRxiv a license to display the preprint in perpetuity.

It is made available under a CC-BY-NC-ND 4.0 International license .

354

355

356

Table 3: Cox regression analysis of predictors of death in patients $\geq 3$ years with $S$. aureus pneumonia, including clinical predictors at admission and microbiological predictors.

\begin{tabular}{|c|c|c|c|}
\hline \multirow[b]{2}{*}{ Predictor } & \multicolumn{3}{|c|}{ Hazard ratio ( $95 \%$ confidence interval) } \\
\hline & Bivariate models & Full model & Best-fitting model \\
\hline $\begin{array}{l}\text { Charlson comorbidity score (per } \\
\text { point) }\end{array}$ & $1.05(0.91$ to 1.21$)$ & $1.03(0.85$ to 1.26$)$ & - \\
\hline Male sex & $0.68(0.39$ to 1.17$)$ & $0.95(0.51$ to 1.78$)$ & - \\
\hline PVL & $1.95(1.12$ to 3.41$)$ & $0.87(0.42$ to 1.83$)$ & - \\
\hline Methicillin resistance & $2.57(1.41$ to 4.69$)$ & $3.86(1.34$ to 11.16$)$ & $2.87(1.53$ to 5.40$)$ \\
\hline SOFA score & $1.11(1.05$ to 1.16$)$ & $1.03(0.96$ to 1.11$)$ & - \\
\hline Flu-like illness & $0.71(0.41$ to 1.23$)$ & $0.32(0.15$ to 0.68$)$ & $0.32(0.17$ to 0.60$)$ \\
\hline Hemoptysis & $2.62(1.52$ to 4.52$)$ & $1.87(0.98$ to 3.54$)$ & $2.15(1.17$ to 3.93$)$ \\
\hline Rash & $2.17(1.12$ to 4.23$)$ & $2.59(1.22$ to 5.48$)$ & $2.52(1.24$ to 5.12$)$ \\
\hline Leukopenia & $3.45(2.00$ to 5.97$)$ & 2.38 (1.19 to 4.76$)$ & $2.38(1.23$ to 4.58$)$ \\
\hline $\begin{array}{l}\text { Blood procalcitonin (per 2-fold } \\
\text { increase) }\end{array}$ & $1.40(1.21$ to 1.63$)$ & $1.05(0.88$ to 1.24$)$ & - \\
\hline $\begin{array}{l}\text { Blood lactates (per 2-fold } \\
\text { increase) }\end{array}$ & $2.40(1.85$ to 3.12$)$ & $2.23(1.52$ to 3.28$)$ & 2.64 (1.95 to 3.57$)$ \\
\hline Adapted antimicrobial therapy & $0.82(0.44$ to 1.53$)$ & $1.54(0.52$ to 4.59$)$ & - \\
\hline Antitoxin therapy & $2.67(1.48$ to 4.81$)$ & $1.29(0.63$ to 2.65$)$ & - \\
\hline $\begin{array}{l}\text { NOTE. Bivariate models were in } \\
\text { multivariate model included all p } \\
420 \text { with } 13 \text { degrees of freedom). } \\
\text { the full model, and minimizing th } \\
\text { corrected for test multiplicity. PV } \\
\text { assessment score. }\end{array}$ & $\begin{array}{l}\text { dent Cox proportior } \\
\text { tors (likelihood ratio } \\
\text { best-fitting model w } \\
\text { ( } 409 \text { with } 6 \text { degree } \\
\text { anton-Valentine leuk }\end{array}$ & $\begin{array}{l}\text { zards models, one pe } \\
\mathrm{P}<0.001 ; \text { Akaike in } \\
\text { tained using a stepwi } \\
\text { freedom). Confidence } \\
\text { n. SOFA score, seque }\end{array}$ & $\begin{array}{l}\text { ictor. The full } \\
\text { tion criterion [AIC], } \\
\text { cedure, starting from } \\
\text { al widths were not } \\
\text { organ failure }\end{array}$ \\
\hline
\end{tabular}


medRxiv preprint doi: https://doi.org/10.1101/2020.07.31.20162875; this version posted August 4, 2020. The copyright holder for this preprint (which was not certified by peer review) is the author/funder, who has granted medRxiv a license to display the preprint in perpetuity.

It is made available under a CC-BY-NC-ND 4.0 International license .

\section{$358 \quad$ Figures}

359 Figure 1: Mortality of patients with S. aureus community-acquired pneumonia (CAP) 360 according to age and the presence of the Panton-Valentine leukocidin (PVL). Panels a, c, 361 e and $g$ present density estimates of the occurrence of pneumonia in all patients of the 362 considered group (green lines) and in deceased patients (red lines). Panels b, d, f, and h 363 present estimates of mortality rate. Colored areas present bootstrap-based $95 \%$ confidence 364 bands of the estimates. Analyses were conducted separately for all patients (a and b), patients 365 with PVL-positive CAP (c and d), patients with PVL-negative CAP (e and f), and patients $<3$ 366
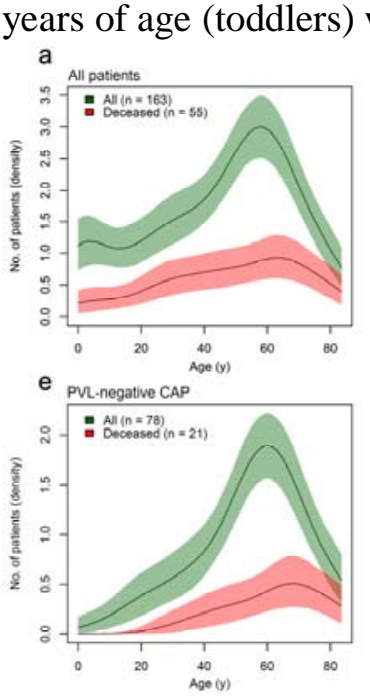
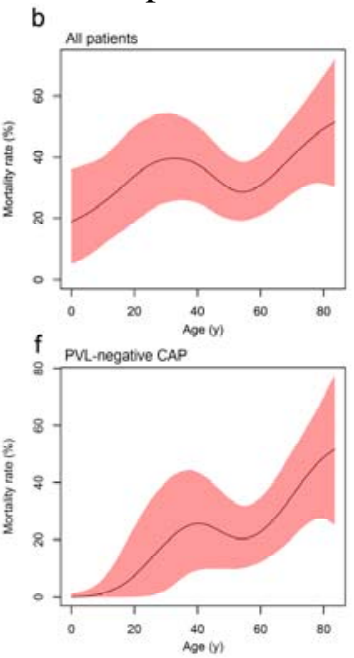
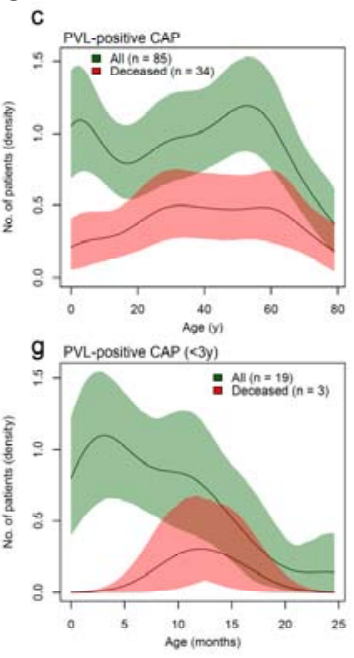
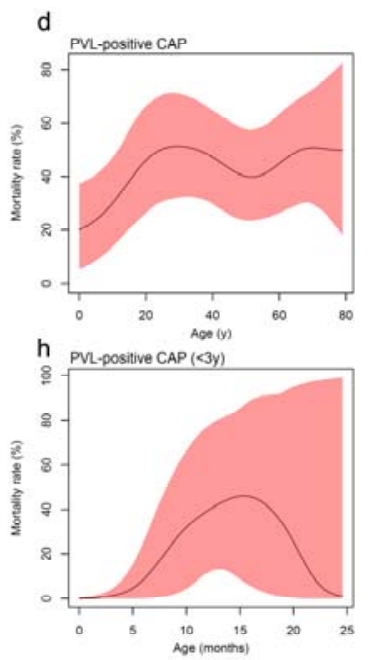
medRxiv preprint doi: https://doi.org/10.1101/2020.07.31.20162875; this version posted August 4, 2020. The copyright holder for this preprint (which was not certified by peer review) is the author/funder, who has granted medRxiv a license to display the preprint in perpetuity.

It is made available under a CC-BY-NC-ND 4.0 International license.

370

371

372

373

374

375

376

377

378

379

380

381

382

383

384

385
Figure 2: Survival of 143 patients $\geq 3$ years of age with $S$. aureus pneumonia. Survival after ICU admission according to whether the causative strain was methicillin-resistant (MRSA) or -susceptible (MSSA) and whether it harbored the PVL toxin are shown. ' + ' marks denote censored (discharged) patients. Log-rank test, $\mathrm{p}=0.0007$.

375 


\section{References.}

388

389

390

391

392

393

394

395

396

397

398

399

400

401

402

403

404

405

406

407

408

409

410

411

412

413

414

415

416

417

418

419

420

421

422

423

424

425

426

427

428

429

430

431

432

433

434

1 Chickering HT, Park JHJ. Staphylococcus aureus pneumonia. JAMA 1919;72:617-26.

2 Gillet Y, Issartel B, Vanhems P, et al. Association between Staphylococcus aureus strains carrying gene for Panton-Valentine leukocidin and highly lethal necrotising pneumonia in young immunocompetent patients. Lancet 2002;359:753-9.

3 Wollenman OJ, Finland M. Pathology of Staphylococcal Pneumonia Complicating Clinical Influenza. Am J Pathol 1943;19:23-41.

4 Centers for Disease Control and Prevention (CDC). Four pediatric deaths from communityacquired methicillin-resistant Staphylococcus aureus - Minnesota and North Dakota, 19971999. MMWR Morb Mortal Wkly Rep 1999;48:707-10.

5 Lina G, Piémont Y, Godail-Gamot F, et al. Involvement of Panton-Valentine leukocidinproducing Staphylococcus aureus in primary skin infections and pneumonia. Clin Infect Dis 1999;29:1128-32.

6 David MZ, Daum RS. Community-associated methicillin-resistant Staphylococcus aureus: epidemiology and clinical consequences of an emerging epidemic. Clin Microbiol Rev 2010;23:616-87.

7 Kreienbuehl L, Charbonney E, Eggimann P. Community-acquired necrotizing pneumonia due to methicillin-sensitive Staphylococcus aureus secreting Panton-Valentine leukocidin: a review of case reports. Ann Intensive Care 2011;1:52.

$8 \mathrm{Li} \mathrm{H-T,} \mathrm{Zhang} \mathrm{T-T,} \mathrm{Huang} \mathrm{J,} \mathrm{Zhou} \mathrm{Y-Q,} \mathrm{Zhu} \mathrm{J-X,} \mathrm{Wu} \mathrm{B-Q.} \mathrm{Factors} \mathrm{associated} \mathrm{with} \mathrm{the}$ outcome of life-threatening necrotizing pneumonia due to community-acquired

Staphylococcus aureus in adult and adolescent patients. Respiration 2011;81:448-60.

9 Mandell LA, Wunderink R. Methicillin-resistant Staphylococcus aureus and communityacquired pneumonia: an evolving relationship. Clin Infect Dis 2012;54:1134-6.

10 Hendren WH, Haggerty RJ. Staphylococcic pneumonia in infancy and childhood; analysis of seventy-five cases. J Am Med Assoc 1958;168:6-16.

11 Rebhan AW, Edwards HE. Staphylococcal pneumonia: a review of 329 cases. Can Med Assoc J 1960;82:513-7.

12 Carrillo-Marquez MA, Hulten KG, Hammerman W, Lamberth L, Mason EO, Kaplan SL. Staphylococcus aureus pneumonia in children in the era of community-acquired methicillinresistance at Texas Children's Hospital. Pediatr Infect Dis J 2011;30:545-50.

13 Lemaître C, Angoulvant F, Gabor F, et al. Necrotizing Pneumonia in Children: Report of 41 Cases Between 2006 and 2011 in a French Tertiary Care Center. Pediatr Infect Dis J 2013;32:1146-9.

14 Shallcross LJ, Fragaszy E, Johnson AM, Hayward AC. The role of the Panton-Valentine leucocidin toxin in staphylococcal disease: a systematic review and meta-analysis. Lancet Infect Dis 2013;13:43-54.

15 Bubeck Wardenburg J, Palazzolo-Ballance AM, Otto M, Schneewind O, DeLeo FR. Panton-Valentine leukocidin is not a virulence determinant in murine models of communityassociated methicillin-resistant Staphylococcus aureus disease. J Infect Dis 2008;198:116670 .

16 Diep BA, Gillet Y, Etienne J, Lina G, Vandenesch F. Panton-Valentine leucocidin and pneumonia. Lancet Infect Dis 2013;13:566.

17 Tristan A, Rasigade J-P, Ruizendaal E, et al. Rise of CC398 lineage of Staphylococcus aureus among Infective endocarditis isolates revealed by two consecutive population-based studies in France. PLoS One 2012;7:e51172.

18 van der Heijden GJMG, Donders ART, Stijnen T, Moons KGM. Imputation of missing values is superior to complete case analysis and the missing-indicator method in multivariable 
diagnostic research: a clinical example. J Clin Epidemiol 2006;59:1102-9.

19 Gillet Y, Vanhems P, Lina G, et al. Factors predicting mortality in necrotizing communityacquired pneumonia caused by Staphylococcus aureus containing Panton-Valentine leukocidin. Clin Infect Dis 2007;45:315-21. 20 Richiardi L, Bellocco R, Zugna D. Mediation analysis in epidemiology: methods, interpretation and bias. Int J Epidemiol 2013;42:1511-9.

21 Patterson CM, Loebinger MR. Community acquired pneumonia: assessment and treatment. Clin Med (Lond) 2012;12:283-6.

22 Diep BA, Palazzolo-Ballance AM, Tattevin P, et al. Contribution of Panton-Valentine leukocidin in community-associated methicillin-resistant Staphylococcus aureus pathogenesis. PLoS One 2008;3:e3198.

23 Niemann S, Ehrhardt C, Medina E, et al. Combined action of influenza virus and Staphylococcus aureus panton-valentine leukocidin provokes severe lung epithelium damage. J Infect Dis 2012;206:1138-48.

24 Perret M, Badiou C, Lina G, et al. Cross-talk between Staphylococcus aureus leukocidinsintoxicated macrophages and lung epithelial cells triggers chemokine secretion in an inflammasome-dependent manner: Macrophage-epithelia cross-talk upon PVL treatment. Cell Microbiol 2012;14:1019-36.

25 Singer M, Deutschman CS, Seymour CW, et al. The Third International Consensus Definitions for Sepsis and Septic Shock (Sepsis-3). JAMA 2016;315:801-10.

26 Casserly B, Phillips GS, Schorr C, et al. Lactate measurements in sepsis-induced tissue hypoperfusion: results from the Surviving Sepsis Campaign database. Crit Care Med 2015;43:567-73.

27 Gijón M, Bellusci M, Petraitiene B, et al. Factors associated with severity in invasive community-acquired Staphylococcus aureus infections in children: a prospective European multicentre study. Clin Microbiol Infect 2016;22:643.e1-6.

28 Jacquot A, Luyt C-E, Kimmoun A, Levy B, Baux E, Fluvalentine Study group. Epidemiology of post-influenza bacterial pneumonia due to Panton-Valentine leucocidin positive Staphylococcus aureus in intensive care units: a retrospective nationwide study. Intensive Care Med 2019;45:1312-1314. 29 Hsu L-Y, Koh T-H, Anantham D, Kurup A, Chan KPW, Tan B-H. Panton-Valentine leukocidin-positive Staphylococcus aureus, Singapore. Emerg Infect Dis 2004;10:1509-10. 30 Holmes A, Ganner M, McGuane S, Pitt TL, Cookson BD, Kearns AM. Staphylococcus aureus isolates carrying Panton-Valentine leucocidin genes in England and Wales: frequency, characterization, and association with clinical disease. J Clin Microbiol 2005;43:2384-90. 31 Francis JS, Doherty MC, Lopatin U, et al. Severe community-onset pneumonia in healthy adults caused by methicillin-resistant Staphylococcus aureus carrying the Panton-Valentine leukocidin genes. Clin Infect Dis 2005;40:100-7.

32 Finelli L, Fiore A, Dhara R, et al. Influenza-associated pediatric mortality in the United States: increase of Staphylococcus aureus coinfection. Pediatrics 2008;122:805-11. 33 Dufour P, Gillet Y, Bes M, et al. Community-acquired methicillin-resistant Staphylococcus aureus infections in France: emergence of a single clone that produces Panton-Valentine leukocidin. Clin Infect Dis 2002;35:819-24. 